\title{
Virginie Greene, Le sujet et la mort dans «La Mort Artu»
}

\section{G. Matteo Roccati}

\section{Q OpenEdition}

10 Journals

\section{Édition électronique}

URL : https://journals.openedition.org/studifrancesi/40292

DOI : $10.4000 /$ studifrancesi. 40292

ISSN : 2421-5856

Éditeur

Rosenberg \& Sellier

\section{Édition imprimée}

Date de publication : 1 juillet 2004

Pagination : 157

ISSN : 0039-2944

\section{Référence électronique}

G. Matteo Roccati, «Virginie Greene, Le sujet et la mort dans «La Mort Artu» », Studi Francesi [En ligne], 142 (XLVIII | I) | 2004, mis en ligne le 30 novembre 2015, consulté le 09 septembre 2021. URL : http:// journals.openedition.org/studifrancesi/40292 ; DOI : https://doi.org/10.4000/studifrancesi.40292

Ce document a été généré automatiquement le 9 septembre 2021.

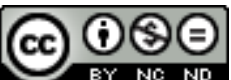

Studi Francesi è distribuita con Licenza Creative Commons Attribuzione - Non commerciale - Non opere derivate 4.0 Internazionale. 


\title{
Virginie Greene, Le sujet et la mort dans «La Mort Artu»
}

\author{
G. Matteo Roccati
}

\section{RÉFÉRENCE}

VIRGINIE GREENE, Le sujet et la mort dans «La Mort Artu», Saint-Genouph, Librairie Nizet, 2002 , pp. 418.

1 Le livre se construit à partir des questionnements freudiens que suscite La Mort Artu, les données établies par 1a critique étant utilisées pour saisir le lien entre l'«être soi» et la mort, l'inquiétude à 1'égard de cette dernière constituant le sujet.

2 Un premier chapitre parcourt les œuvres consacrées à la mort dans les années 1950-2000. L'exposé porte ensuite sur 1a question de l'auteur, du lieu de production et du milieu d'origine du texte, telle qu'elle est abordée dans les études modernes et au Moyen Age (II), sur le personnage d'Arthur tel qu'il apparait dans l'histoire et dans la fiction (III), sur le sujet et la mort («filtre interprétatif du récit», p. 183) dans la structure du roman (IV), enfin sur les «trois chemins menant à 1a mort» (ibid.) symbo1isés par les trois personnages dont la mort est inscrite depuis le début dans le roman: Gauvain (V), Arthur (VI), Lancelot (VII). La bibliographie (pp. 391-416) termine le volume. 